\title{
Inhibition of Protein 4.1R and NuMA Interaction by Mutagenization of Their Binding-Sites Abrogates Nuclear Localization of 4.1R
}

\author{
Subhendra N. Mattagajasingh, Ph.D. ${ }^{,}$, Shu-Ching Huang, Ph.D. ${ }^{\text {, }}$ and Edward J. Benz, Jr., M.D., F.A.C.P2,3
}

\begin{abstract}
Protein 4.1R (4.1R) is a multifunctional structural protein recently implicated in nuclear assembly and cell division. We earlier demonstrated that 4.1R forms a multiprotein complex with mitotic spindle and spindle pole organizing proteins, such as NuMA, dynein, and dynactin, by binding to residues 1788-1810 of NuMA through amino acids encoded by exons 20 and 21 in 24 kD domain. Employing randomand site-directed mutagenesis combined with glycine- and alanine-scanning, we have identified amino acids of 4.1R and NuMA that sustain their interaction, and have analyzed the effect of mutating the binding sites on their intracellular colocalization. We found that V762, V765, and V767 of 4.1R, and I1800, I1801, I 1803, T1804, and M 1805 of NuMA are necessary for their interaction. GST-fusion peptides of the 4.1R 24 kD domain bound to residues 1785-2115 of NuMA in in vitro binding assays, but the binding was inhibited by alanine substitutions of V762, V765, and V767 of 4.1R, or residues 1800-1805 of NuMA. Additionally, expression of variants of 4.1R or NuMA that inhibit their in vitro binding also abrogated nuclear localization of 4.1R and colocalization with NuMA. Our findings suggest a crucial role of 4.1R/NuMA interaction in localization and function of $4.1 \mathrm{R}$ in the nucleus.
\end{abstract}

Keywords: Protein 4.1R, NuMA, mitotic spindle, nuclear localization, mutagenesis

\section{Introduction}

Protein $4.1 \mathrm{R}(4.1 \mathrm{R})$ was initially characterized as an $80 \mathrm{kD}$ structural protein important for mechanical stability and elasticity of the erythrocyte cell membrane. ${ }^{1}$ Multiple isoforms of $4.1 \mathrm{R}$ are expressed in nucleated cells ${ }^{2,3}$ that arise from a single gene by usage of different promoters, ${ }^{4}$ at least two different initiation sites, ${ }^{5,6}$ alternative mRNA splicing, ${ }^{7,8}$ and posttranslational modifications. ${ }^{9}$ Additionally, three homologs of $4.1 \mathrm{R}$, namely $4.1 \mathrm{G},{ }^{10} 4.1 \mathrm{~B}^{11}$, and $4.1 \mathrm{~N},{ }^{12}$ have been identified. These share strong homology with the $30 \mathrm{kD}$ membrane-binding domain, $10 \mathrm{kD}$ spectrin/actin-binding domain (SABD), and the $24 \mathrm{kD} \mathrm{COOH}$ terminal domain (CTD) of 4.1R.

In nonerythroid cells, epitopes for 4.1R localize in multiple subcellular compartments. $4.1 \mathrm{R}$ has been reported to localize at cell-cell and cell-matrix contacts, ${ }^{13-15}$ along the stress fibers, ${ }^{13}$ in perinuclear regions ${ }^{16,17}$ and in the nucleus and the nuclear matrix. ${ }^{18-22}$ Different molecular signals have been identified that regulate intracellular targeting of 4.1R isoforms. Exons 8-13 and the constitutively expressed residues of exon 17, designated as the "core region," have been suggested as the core signal necessary for 4.1R nuclear import, whereas exon 5 and the 209 amino acid $\mathrm{NH}_{2}$-terminal extension found in higher molecular mass $4.1 \mathrm{R}$ isoforms promote cytoplasmic localization. ${ }^{23,24}$ However, the molecular signals that determine the nuclear localization of 4.1R need further characterization.

A number of proteins that bind to different domains of $4.1 \mathrm{R}$ in erythroid and nonerythroid cells have been identified that provide clues to specific functions of its domains. Protein 4.1 has been reported to bind to the centrosome protein 4.1-associated protein, CPAP, ${ }^{25}$ and calmodulin ${ }^{26}$ through an $\mathrm{NH}_{2}$-terminal extension found in nucleated cells; to glycophorin $\mathrm{C},{ }^{27}$ calmodulin, ${ }^{28} \mathrm{p} 55,{ }^{27}$ band $3,{ }^{29} \mathrm{CD} 44,{ }^{30}$ a cellular volume control protein, pICIn, ${ }^{31}$ and microtubules ${ }^{32}$ through its $30 \mathrm{kD}$ domain; to spectrin and $\operatorname{actin}^{33-35}$ (33-35), and importin $\alpha,{ }^{36}$ through the $10 \mathrm{kD}$ spectrinactin binding (SAB) domain; and to $\mathrm{ZO}-2,{ }^{15} \mathrm{FKBP} 13,{ }^{37} \mathrm{eIF} 3,{ }^{38}$ and the nuclear mitotic apparatus protein, NuMA, ${ }^{22}$ through the $24 \mathrm{kD}$ COOH-terminal domain.

In an earlier study, ${ }^{22}$ we demonstrated that a $135 \mathrm{kD} 4.1 \mathrm{R}$ isoform associates with mitotic spindle pole organizing proteins such as NuMA, dynein and dynactin, by directly binding to NuMA through residues that reside within exons 20 and 21 of 4.1R, and amino acids 1788-1810 of NuMA. These findings have been confirmed and extended, and a critical role of 4.1R in nuclear assembly and microtubule dynamics and organization during cell division has been revealed. ${ }^{32,39,40}$ In this study, by employing an in vitro mutagenesis approach, we have identified amino acids of both 4.1R and NuMA that are indispensable for their interaction, and have examined the effect of ectopic expression of mutant $4.1 \mathrm{R}$ and mutant NuMA peptides that inhibit 4.1R/NuMA interaction, on nuclear localization of 4.1R and NuMA. Our findings implicate an important role of $4.1 \mathrm{R} / \mathrm{NuMA}$ interaction in localization and function of $4.1 \mathrm{R}$ in the nucleus.

\section{Materials and Methods}

Random and site-directed mutagenesis, and construction of expression vectors

The construction of 4.1R exon 20-21/pAS2-1 and NuMA 1788$1810 /$ pACT2 have been described. ${ }^{22}$ Random mutants of $4.1 \mathrm{R}$ and NuMA segments corresponding to their amino acids (aa) 718-776 and 1788-1810, respectively, were generated by PCR amplification in conditions that reduced the fidelity of DNA polymerase. For amplification of each gene, four PCR mixtures were prepared. Each mixture contained $100 \mathrm{nM}$ each of $3 \mathrm{dNTPs}$ and $10 \mathrm{nM}$ of the fourth dNTP, $90 \mathrm{nM}$ dITP, $5 \mathrm{mM} \mathrm{MgCl}$, Taq polymerase, 1/10 volume PCR buffer (Invitrogen, Carlsbad, CA, USA) and the primers. The amplified 4.1R and NuMA fragments were subcloned into Gal4 yeast two-hybrid vectors, pAS2-1 and pACT2, respectively, following standard methods, and all the clones were isolated separately.

'Cardiovascular Institute, University of Pittsburgh Medical Center, Pittsburgh, Pennsylvania, USA; ${ }^{2}$ Department of Medical Oncology, Dana Farber Cancer Institute and Department

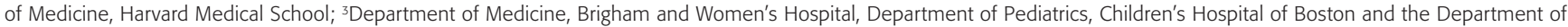
Pathology, Harvard Medical School, Boston, Massachusetts, USA. Correspondence: EJ Benz,Jr. (Edward_benz@dfci.harvard.edu)

S. N. Mattagajasingh designed the research, performed the research, analyzed the data, and wrote the paper. S.-C. Huang designed the research, performed the research, and analyzed the data. E. J. Benz, Jr. designed the research, analyzed the data, and wrote the paper.

DOI: $10.1111 /$ j.1752-8062.2008.00087.x 
For identification of random mutants, each NuMA clone (encoded by pACT2/NuMA aa 1788-1810) was tested for its interaction with $4.1 \mathrm{R}$ exons $20-21$ and its $24 \mathrm{kD}$ domain (encoded by pAS2-1/4.1R exons $20-21$ or pAS2-1/4.1R exons 17-21, respectively) in yeast two-hybrid assays, as described. ${ }^{22}$ The random mutants of $4.1 \mathrm{R}$ and NuMA, that failed to interact with their respective wild-type binding partners in yeast two-hybrid assays, were manually sequenced, and the mutant residues were identified. NuMA (aa 1788-1810) point mutants T1798P, I1800S, I1800T, T1804P, T1806P, I1800G, I1801G, N1802G, I1803G, T1804G, M1805G, T1806G, I1800A, I1801A, N1802A, I1803A, T1804A, M1805A, and T1806A, and 4.1R exon 20-21 point mutants V719A, I723A, R727A, I728A, E729A, K730A, R731G, R731A, I732A, V733G, V733A, I734A, T735A, A738G, I740G, I740A, V745G, V747G, E755A, P758A, S761A, V762A, T763A, K764A, V765G, V765A, V766A, V767A, and $\mathrm{H} 768 \mathrm{~A}$ were generated by site-directed mutagenesis using specially designed primer sets and two-step overlap PCR, as described, ${ }^{22}$ and subcloned in frame into pACT2 and pAS2-1, respectively. A tandem mutant of $4.1 \mathrm{R}$ encoding exons 20-21 with V762A, V765A, V767A substitutions (4.1R 20,21 mut3A) was subcloned into pAS2-1 for expression of the mutant peptide as Gal4-binding domain (BD) fusion-protein. NuMA aa 1788-1888 (NuMA- $\Delta$ C) with tandem alanine substitutions, I1800A, I1801A, N1802A, I1803A, T1804A, and M1805A (NuMA- $\Delta$ C mut6A) were subcloned into pACT2 for expression of the mutant peptides as Gal4-activation domain (AD) fusion-protein.

Protein 4.1R exon 20-21 deletion constructs encoding aa 727-776 and 736-776 were constructed in pAS2-1 by PCR amplification, and were derived from $4.1 \mathrm{R} 24 \mathrm{kD} / \mathrm{pAS} 2-1 .{ }^{22}$ Protein $4.1 \mathrm{R} 10 \mathrm{kD}, 24 \mathrm{kD}$ and $10+24 \mathrm{kD}$ domains were amplified using the following primer sets: $10 \mathrm{kD}$ (nt 1785-1807/1900-1922), $24 \mathrm{kD}$ (nt 1923-1942/2354-2374), 10+24 kD (1785-1807/23542374) (accession number J03796) and subcloned in frame into pEGFP-C2. Protein 4.1R $24 \mathrm{kD}$ domain with V762A, V765A, V767A substitutions (4.1R $24 \mathrm{kD}$ mut3A) was derived from $24 \mathrm{kD} / \mathrm{pAS} 2-1$ by two-step overlap PCR, and subcloned into pEGFP-C2 and pGEX-6P1 for expression as green fluorescent protein (GFP) and GST fusion-proteins, respectively. NuMA aa 1785-2115 (NuMA-C) and with I1800A, I1801A, N1802A, I1803A, T1804A, and M1805A substitutions (NuMA- $\Delta$ C mut6A) were derived from NuMA 1697-2115/pACT2, ${ }^{22}$ and subcloned in frame into $\mathrm{pCR}^{\circledR}$ Blunt-II TOPO and pEFGP-C1 vectors for expression of the peptides in the $\mathrm{TNT}^{\circledR}$ rabbit reticulocyte lysate system, and as GFP-fusion proteins, respectively. The authenticity of all deletions and mutations was confirmed by manual dideoxy sequencing. The amino acid and nucleotide numbers were assigned according to GenBank/EMBL/DDBJ accession number J03796 and NM_006185 for protein 4.1R and NuMA, respectively.

\section{Yeast Two-hybrid assay}

The Gal4-based MATCHMAKER two-hybrid system II (Clontech Lab, Palo Alto, CA, USA) was followed for analysis of proteinprotein interaction in yeast two-hybrid assays. Wild-type and mutant 4.1R and NuMA segments were cloned in frame into the Gal4-BD vector, pAS2-1 and the Gal4-AD vector, pACT2, respectively. The desired wild-type or mutant segments of $4.1 \mathrm{R}$ and NuMA were coexpressed in S. cerevisiae strain Y190, and expression of the reporter gene(s) was detected as described earlier. ${ }^{15,22}$

\section{In vitro binding assay}

NuMA-C/TOPO and NuMA-C mut6A/TOPO were in vitro translated using the $\mathrm{TNT}^{\circledR}$ coupled reticulocyte lysate system and $\left[{ }^{35} \mathrm{~S}\right]$ methionine as per the manufacturer's suggestions (Promega Corp., Madison, WI, USA). GST alone or GST-fusion proteins encoding 4.1R $16 \mathrm{kD}, 24 \mathrm{kD}$ or $24 \mathrm{kD}$ with V762A, V765A, and V767A tandem mutations (4.1R $24 \mathrm{kD}$ mut3A) were affinity purified by coupling to glutathione-Sepharose beads as described earlier (not shown). ${ }^{22}$ Equal amounts of in vitro translated wildtype or mutant NuMA proteins were incubated with about $10 \mu \mathrm{g}$ GST or GST-4.1R polypeptides. In vitro binding and detection of $\left[{ }^{35} \mathrm{~S}\right]$ methionine labeled NuMA bound to GST-4.1R polypeptides by fluorography were done as described earlier. ${ }^{15,22}$

\section{Cell culture and transfection}

HeLa (ATCC CCL 2, human cervix epitheloid carcinoma) cells were cultured and maintained as described. ${ }^{22}$ Cells were transiently transfected with expression vectors encoding GFP-fusion proteins of different segments of wild-type or mutant 4.1R, GFP-NuMA, or the pEGFP-C1 vector using the LipofectAmine ${ }^{\mathrm{TM}}$ reagent as per the manufacturer's suggestions (Invitrogen). Cells were analyzed $24 \mathrm{~h}$ following transfection.

\section{Immunofluorescent staining and confocal microscopy}

$\mathrm{HeLa}$ cells were grown on cover-glass coated with poly-L-lysine. Cells were transfected with GFP-4.1R or GFP-NuMA expression constructs. Following $24 \mathrm{~h}$ of transfection, cell monolayers on cover glasses were washed in PBS, fixed in $0.4 \%$ paraformaldehyde and permeabilized with $0.5 \%$ Triton X-100 containing $10 \%$ normal goat serum in PBS. Immunofluorescent staining specific for 4.1R or NuMA was carried out as described earlier using Texas Red-conjugated secondary antibodies. ${ }^{22}$ The confocal images were taken at room temperature using a Noran confocal laser scanning image system and a Zeiss Axiophot fluorescent microscope equipped with Plan Fluor 20x and Plan Apo 60x, 1.4 NA oil immersion lenses. Images were acquired using Intervision software (Noran Instruments Inc., Middleton, WI, USA) and processed using Photoshop (Adobe).

\section{Results}

\section{Identification of NuMA amino acids necessary for interaction with 4.1R}

We had previously demonstrated that the amino acids necessary for 4.1R/NuMA interaction reside within exons 20-21 of 4.1R, and amino acid (aa) $1788-1810$ of $\mathrm{NuMA}^{22}$ (Figure 1). To identify the precise amino acids of NuMA necessary for interaction with 4.1R, we tested $57 \mathrm{NuMA}$ random mutants for their ability to interact with $4.1 \mathrm{R}$ amino acids encoded by exon 20-21 or the $24 \mathrm{kD}$ domain in yeast two-hybrid assays. The three random mutants of NuMA that failed to interact with $4.1 \mathrm{R}$ were found to have (1) a T1804P, (2) I1800T and T1804P, and (3) T1798P, I1800S and T1806P substitutions (Figure $2 A$ ). Interaction of single point mutants of NuMA with 4.1R revealed that NuMA I1800T, T1804P or T1806P, but not the T1798P mutation, inhibited interaction with $4.1 \mathrm{R}$ (Figure $2 B$ ). The NuMA/4.1R interaction was also partially inhibited by I1800S substitution of NuMA.

Preliminary experiments suggested I1800 to be necessary for interaction with $4.1 \mathrm{R}$; and V762 of $4.1 \mathrm{R}$ was identified as one of the residues required for interaction with NuMA (see below). We thus hypothesized that 4.1R/NuMA interactions, 


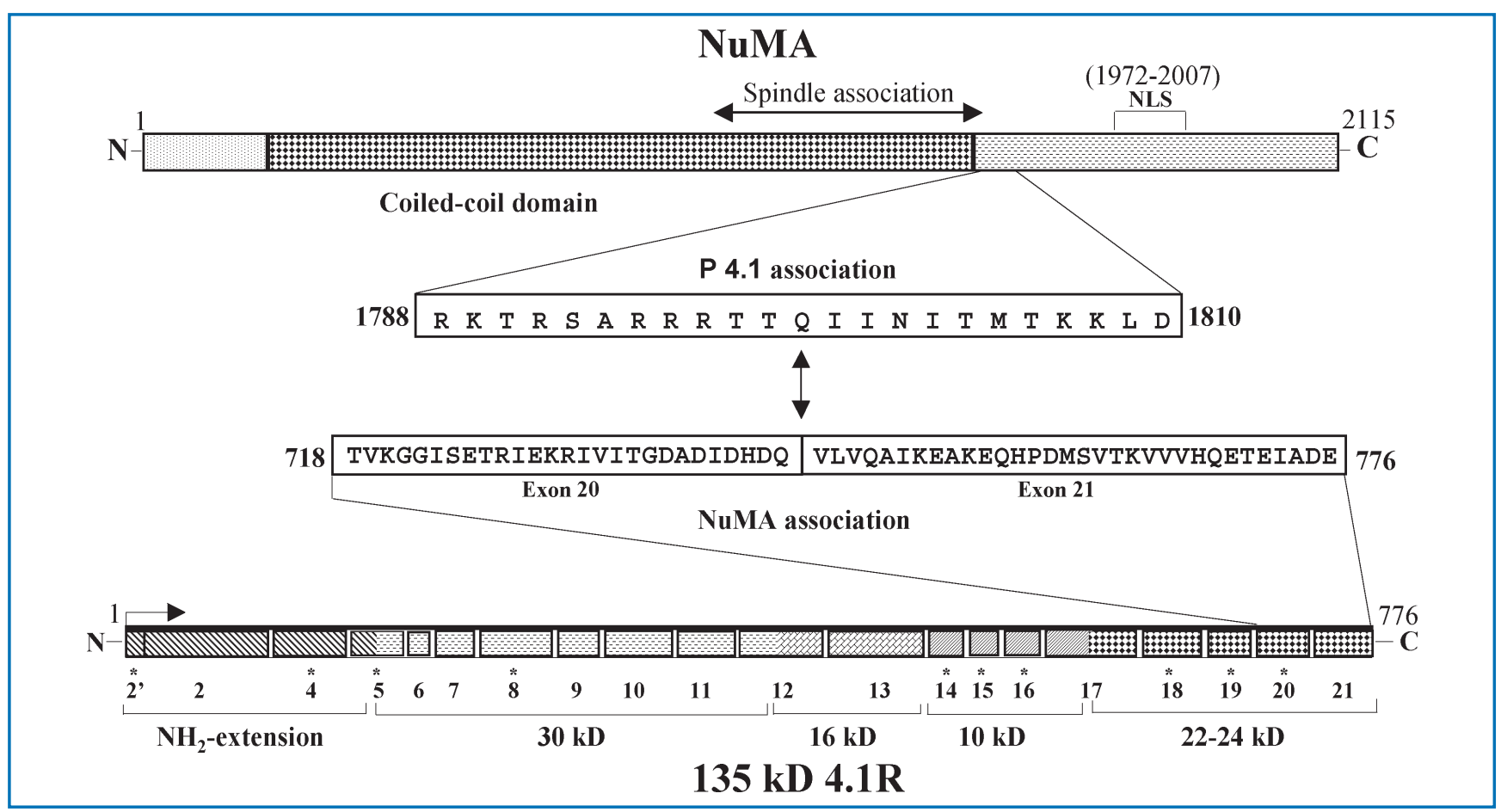

Figure 1. Schematic representation of organization of 4.1R and NuMA proteins, and the corresponding domains necessary and sufficient for their interaction. A schematic representation of NuMA protein and its aa 1788-1810 necessary for interaction with 4.1R are shown. Also shown are schematic representations of the organization of protein $4.1 R$ and the amino acid composition of its exon 20 and 21 necessary for binding to NuMA, different exons representing the 4.1R gene and the corresponding domains. Alternatively spliced exons are indicated by asterisk. NLS, nuclear localization signal.

\section{A : Random mutagenesis}

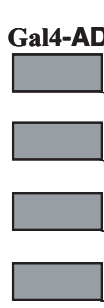

Gal4-AD

1788 R K T R S A R R R T T Q I I N I T M T K K L D 1810

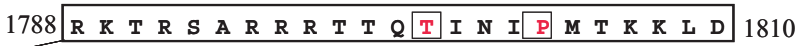

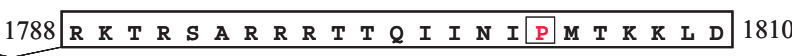

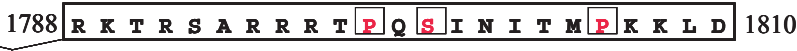

\section{B : Site-directed mutagenesis}

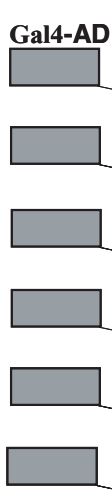
1788 R K T R S A R R R T T Q I I N I T M T K K L D

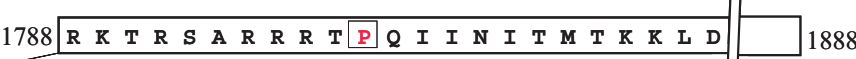

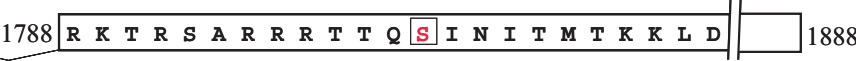

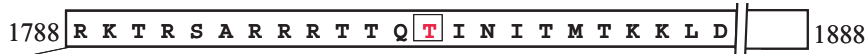

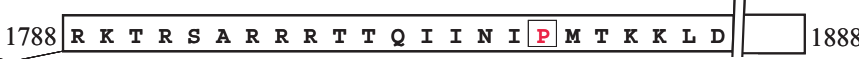

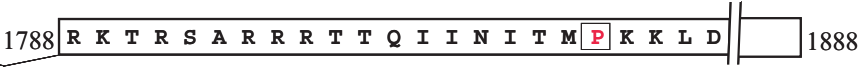

$\beta$-gal activity of yeast co-transformed with protein 4.1R C-terminal domain in pAS2-1

Exons 20-21 Exons 17-21

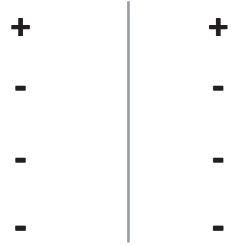

$\beta$-gal activity of yeast co-transformed with protein 4.1R C-terminal domain in pAS2-1

Exons 20-21 Exons 17-21

Figure 2. Characterization of the interaction of 4.1R and NuMA mutants generated by random- and site-directed-mutagenesis. Mutants of NuMA aa $1788-1810$ generated by random mutagenesis (A), or aa 1788-1888 generated by site-directed mutagenesis (B), and wt 4.1R exon 20-21 or the $24 \mathrm{kD}$ domain were coexpressed as Gal4-AD and Gal4-BD fusion proteins, respectively, in yeast strain Y190 and were assayed for expression of the reporter genes as described in "Materials and Methods." (++) indicates the expression of the reporter genes, LacZ and His3 (and thus interaction between the peptides), (+) indicates weak expression of the reporter LacZ gene [as per eye estimation of the blue color of yeast colonies following incubation in X-gal solution for equal amount of time] (and thus weak interaction between the peptides), and ( - ) indicates nonexpression of the reporter genes (and thus no interaction between the peptides). 
Glycine scanning

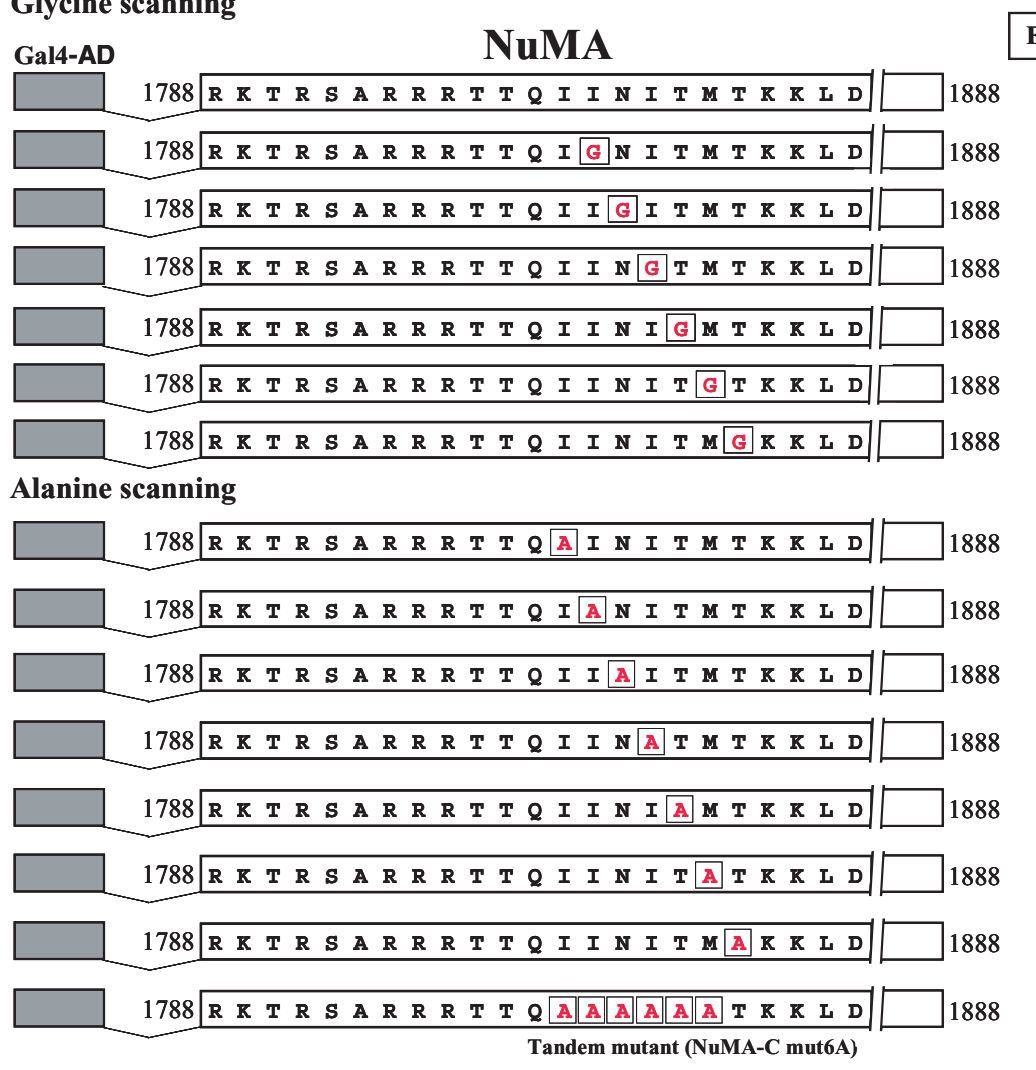

$\beta$-gal activity of yeast co-transformed

with protein 4.1R C-terminal

domain in pAS2-1

\begin{tabular}{c|c|}
\hline Exons 20-21 & Exons 17-21 \\
\hline+ & + \\
+ & - \\
- & + \\
- & - \\
- & - \\
+ & - \\
- & + \\
- & - \\
+ & + \\
- & + \\
- & - \\
\hline
\end{tabular}

Figure 3. Analysis of NuMA aa 1800-1806 for identification of amino acids that bind to 4.1R by "glycine-" and alanine-scanning." Glycine or alanine substitutions generated within NuMA aa 1788-1888 by site-directed mutagenesis (I1801G, I1800A, I1801A, N1802G, N1802A, I1803G, I1803A, T1804G, T1804A, M1805G, M1805A, or T1806A), and 4.1R exon 20-21 or the 24 kD domain were coexpressed as Gal4-AD and Gal4-BD fusion proteins, respectively, in yeast strain Y190 by cotransformation, and were assayed for expression of the reporter genes as described in "Materials and Methods." (+) indicates the expression of the reporter genes, LacZ and His3 (and thus interaction between the peptides) and (-) indicates nonexpression of the reporter genes (and thus no interaction between the peptides).

at least in part, could be sustained by hydrophobic interactions. We targeted a stretch of nonpolar amino acids of NuMA between I1800-T1806, and analyzed them by "glycine scanning” (Figure 3). Glycine substitutions of I1800, I1801, I1803, T1804, and M1805, but not N1802 and T1806, inhibited interaction with $4.1 \mathrm{R}$ exon $20-21$ and with $4.1 \mathrm{R} 24 \mathrm{kD}$ peptides in yeast two-hybrid assays. The failure of NuMA T1806P mutant to interact with $4.1 \mathrm{R}$ (Figure 2) could have been due to altered protein confirmation, proline being a helix breaker. To further confirm that these amino acids of NuMA are necessary for binding to 4.1R, NuMA aa 1800-1806 were analyzed by "alanine scanning." Alanine substitutions of I1800, I1801, N1802, I1803, T1804 and M1805 of NuMA, but not T1806 inhibited interaction with $4.1 \mathrm{R}$ exon $20-21$ and $24 \mathrm{kD}$ peptides (Figure 3). These results suggested that I1800, I1801, I1803, T1804, and M1805 of NuMA are involved in interaction with 4.1R. Of note, all of these residues except T1804 have nonpolar side chains. Taken together, our data suggest that interaction between 4.1R and NuMA could possibly be hydrophobic in nature. Consistent with these results, a tandem mutant of NuMA with I1800A, I1801A, N1802A, I1803A, T1804A, and M1805A substitutions (encoded by pACT2/NuMA- $\Delta \mathrm{C}$ mut6A) did not interact with $4.1 \mathrm{R}$ in yeast two-hybrid assays (Figure 3).
Identification of 4.1R amino acids necessary for interaction with NuMA protein

Amino acids of 4.1R necessary for interaction with NuMA were identified by methods similar to those used for identification of amino acids of NuMA responsible for interaction with 4.1R. Of the 69 random mutant (RM) 4.1R clones analyzed, only four mutants failed to interact with NuMA (Figure 4). Each mutant 4.1R was found to have multiple point mutations: 1) E729G, A738S, and V765L; 2) R731G, P758T, V765E, and H768Q; 3) V733L, I740S, V747G, A755E, and V762A; 4) V745G and V762A. The four $4.1 \mathrm{R}$ random mutants were further analyzed by sitedirected mutagenesis to pinpoint the critical residues. As shown in Figure 4, V762 and V765 of 4.1R proved to be the key residues.

Since exon 20 of $4.1 \mathrm{R}$ was also required for interaction with $\mathrm{NuMA},{ }^{22}$ we next attempted to identify amino acids within $4.1 \mathrm{R}$ exon 20 that might interact with NuMA by targeting all the nonpolar amino acids. As shown in Figure 4, alanine substitution of all the nonpolar amino acids in exon 20 (V719A, I723A, I728A, I732A, V733A, I734A, and I740A) revealed that none of these point mutants inhibit interaction with NuMA in yeast two-hybrid assays. Thus, we performed a deletion analysis of 4.1R exon 20 . Deletion of aa 718-726 from 4.1R peptide encoded by exons 20-21 had no effect on interaction with NuMA, but deletion of aa 718-735 inhibited interaction with NuMA (Figure 4). These 


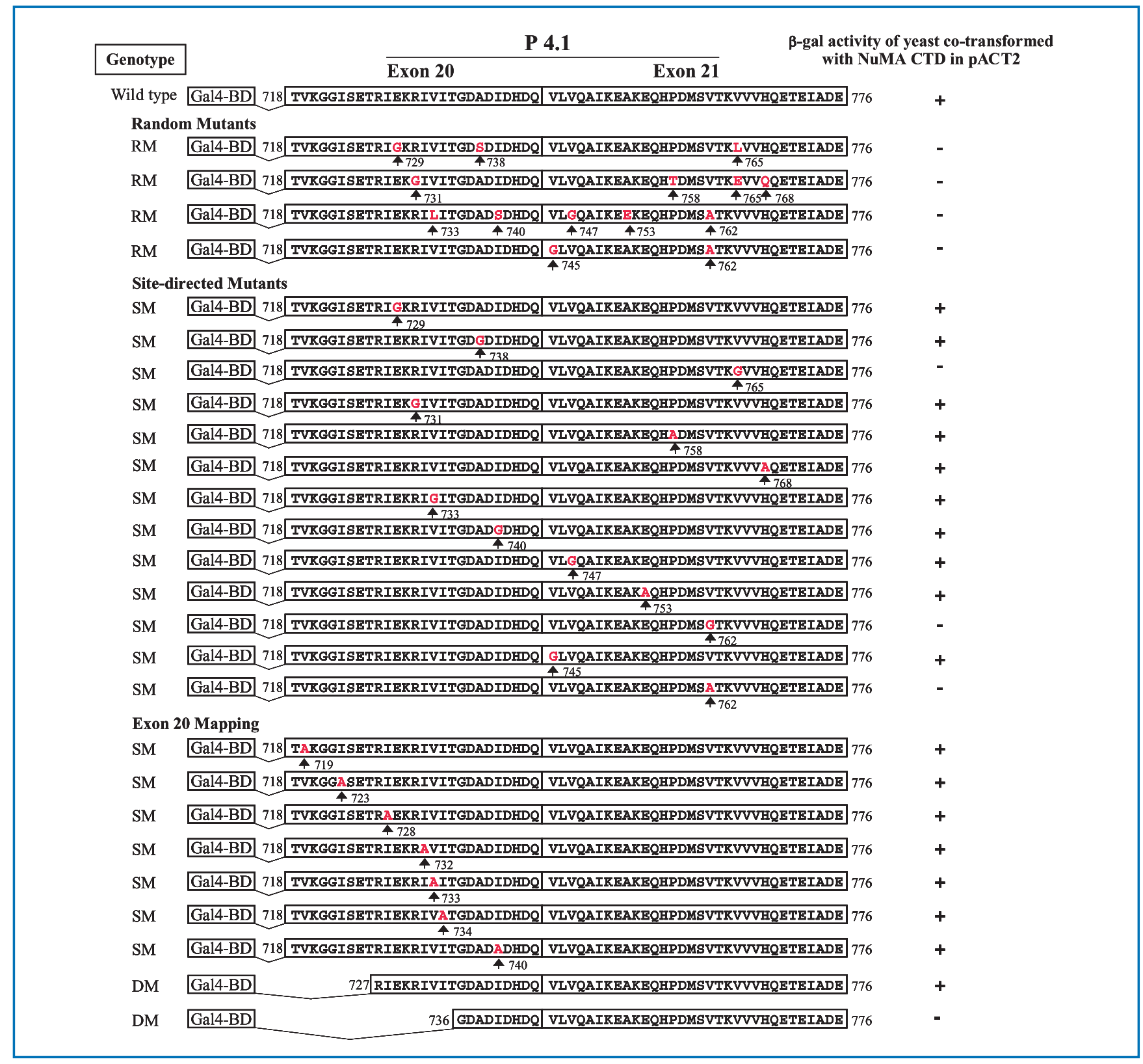

Figure 4. Analysis of 4.1R exon 20 and 21 by random-, site-directed-, and deletional-mutagenesis for identification of residues that interact with NuMA. 4.1R exon 20-21 mutants generated by random-, site-directed-, or deletional-mutagenesis, as shown, and NuMA aa 1785-2115 were coexpressed as Gal4-BD and Gal4-AD fusion proteins, respectively, in yeast strain Y190, and were assayed for expression of the reporter genes as described in "Materials and Methods." (+) indicates expression of the reporter genes, LacZ and His3 (and thus interaction between the peptides) and (-) indicates nonexpression of the reporter genes (and thus no interaction between the peptides). The amino acid substitutions are indicated by arrows. RM, random mutant; SM, site-directed mutant; DM, deletion mutant.

results suggested that 4.1R aa 727-735 of exon 20 may be required for interaction with NuMA.

We next targeted aa 727-735 of exon 20 and a stretch of nonpolar amino acids between S761 and H768 of exon 21 for identification of additional residues that might participate in interaction with NuMA. To our surprise, none of the analine substitutions within residues $727-735$ of $4.1 \mathrm{R}$ inhibited interaction with NuMA (Figure 5), although deletion of these amino acids inhibited the interaction. "Alanine scanning" of 4.1R aa S761H768 revealed that V762A or V765A but not S761A, T763A, K764A, V766A, or H768A substitution inhibits interaction of 4.1R with NuMA (Figure 5). Alanine substitution of V767 also resulted in a partial inhibition of $4.1 \mathrm{R}$ interaction with NuMA.
Consistently, a 4.1R tandem mutant in which V762, V765, and V767 were substituted by alanine (encoded by pAS2-1/4.1R 20,21 mut3A) failed to interact with NuMA in yeast two-hybrid assays. These results suggest that V762, V765, and V767 of 4.1R are necessary for interaction with NuMA, and aa 727-735 of exon 20 may have an accessory role such as providing a particular conformation that facilitates interaction with NuMA.

Alanine substitutions of 4.1R V762, V765, and V767 or amino acids 1800-1805 of NuMA inhibit their interaction in vitro

To confirm the results obtained with yeast two-hybrid assays, the ability of the mutant $4.1 \mathrm{R}$ and mutant NuMA peptides to bind their corresponding wild-type binding partners was tested 


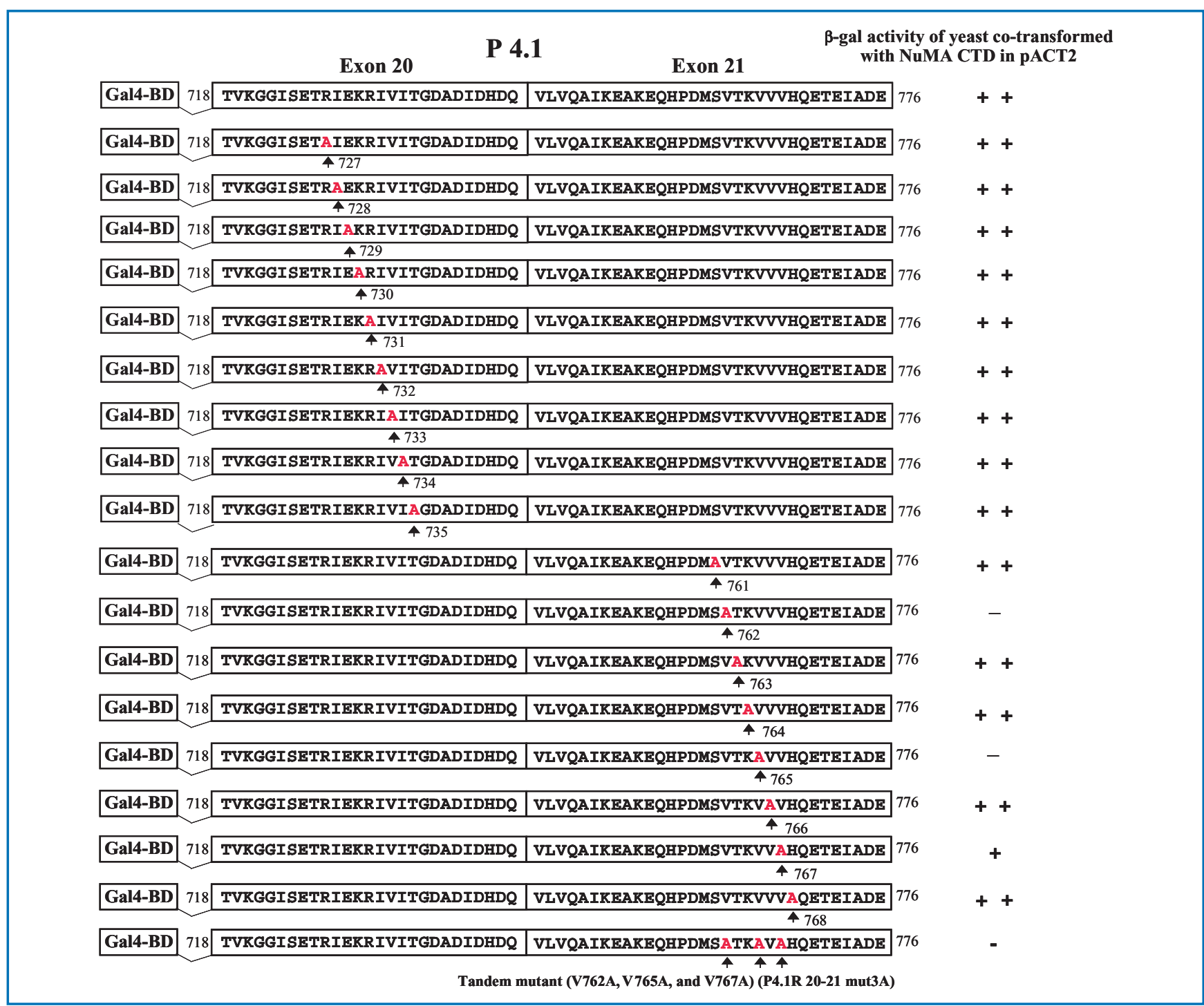

Figure 5. "Alanine scanning" of 4.1R aa 727-735 of exon 20 and aa 761-768 of exon 21 for identification of NuMA-binding residues. Protein 4.1R mutant peptides encoded by exons 20-21 that contained R727A, I728A, E729A, K730A, R731A, 1732A, V733A, 1734A, T735A, S761A, V762A, T763A, K764A, V765A, V766A, V767A, or H768A substitutions were generated by site-directed mutagenesis and coexpressed with NuMA aa 1785-2115 as Gal4-BD and Gal4-AD fusion proteins, respectively, in yeast strain Y190, and were assayed for expression of the reporter genes as described in "Materials and Methods." (++) indicates the expression of the reporter genes, LacZ and His3 (and thus interaction between the peptides), (+) indicates weak expression of the reporter LacZ gene [as per eye estimation of the blue color of yeast colonies following incubation in X-gal solution for equal amount of time] (and thus weak interaction between the peptides), and (-) indicates nonexpression of the reporter genes (and thus no interaction between the peptides). The amino acid substitutions are indicated by arrows.

in in vitro binding assays. Glutathione-S-transferase (GST) alone or GST-fusion proteins of $4.1 \mathrm{R} 16 \mathrm{kD}, 24 \mathrm{kD}$ or $24 \mathrm{kD}$ with V762A, V765A, and V767A tandem mutations (4.1R $24 \mathrm{kD}$ mut3A) were purified (not shown) as described, ${ }^{15,22}$ and in vitro binding was performed using GST-4.1R fusion-proteins and in vitro translated $\left[{ }^{35} \mathrm{~S}\right]$ methionine-labeled NuMA peptides corresponding to aa 1785-2115 with or without the tandem alanine mutations (I1800A, I1801A, N1802A, I1803A, T1804A, and M1805A; NuMA-C mut6A).

Consistent with our previous results, ${ }^{22}$ the NuMA peptides that contained the 4.1R-binding sites (aa 1788-1810) bound to GST-4.1R $24 \mathrm{kD}$, but not to GST alone or GST-4.1R $16 \mathrm{kD}$ (Figure 6A). As anticipated on the basis of yeast-two hybrid assay results, this segment of NuMA bound only weakly to the $4.1 \mathrm{R}$ $24 \mathrm{kD}$ peptide with the tandem alanine mutations $(4.1 \mathrm{R} 24 \mathrm{kD}$ mut3A). No detectable binding was observed between the mutant NuMA (NuMA-C mut6A) and any of the domains of $4.1 \mathrm{R}$ or
GST (Figure 6B). Of note, based on our initial characterization of $4.1 \mathrm{R}$ residues required for interaction with $\mathrm{NuMA},{ }^{41} \mathrm{Krauss}$ et al. ${ }^{39}$ measured the relative affinities of NuMA COOH-terminal peptides (aa 1719-1993) for 4.1R peptides encoded by exons 20-21 with or without the tandem alanine mutations $(4.1 \mathrm{R}$ 20,21 mut3 A) using in vitro binding assays and resonant mirror detection, and reported a sixty-fold decreased affinity for the mutant $4.1 \mathrm{R}$ peptide compared to the wild-type peptide. These results suggest that V762, V765, and V767 of 4.1R, and I1800, I1801, I1803, T1804, and M1805 of NuMA are necessary for their interaction.

Mutagenization of V762, V765, and V767 to alanine inhibits GFP-4.1R $24 \mathrm{kD}$ to localize in the nucleus and colocalize with NuMA

Having defined the reduced affinities of mutant $4.1 \mathrm{R}$ and mutant NuMA for their wild-type binding partners in biochemical 


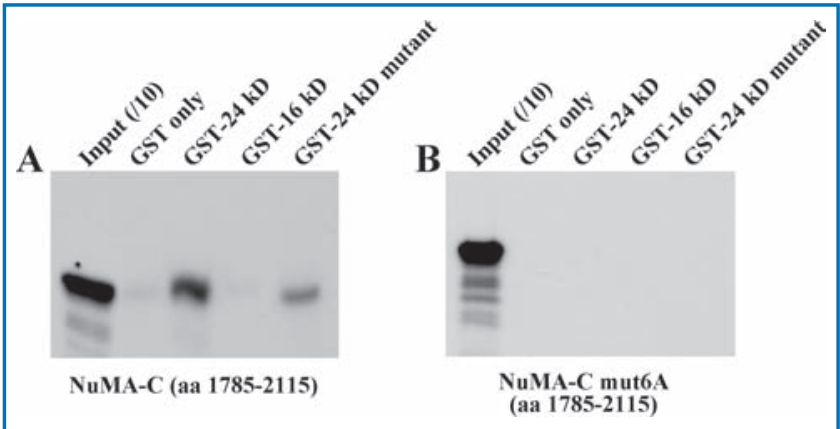

Figure 6. Mutagenization of V762, V765, and V767 of 4.1R or I1800, I1801, 11803 , T1804, and M1805 of NuMA to alanine inhibits interaction with their respective wild-type binding partners in in vitro binding assays. Purified GST-fusion proteins of $4.1 \mathrm{R} 16 \mathrm{kD}, 24 \mathrm{kD}$ or $24 \mathrm{kD}$ mut3A bound to glutathioneSepharose beads were incubated with in vitro translated ${ }^{35} \mathrm{~S}$ ]methione labeled NuMA-C (aa 1785-2115) (A) or NuMA-C mut6A (B). After thorough washing, protein complexes were analyzed by SDS-PAGE and fluorography.

and molecular/genetic assays, we sought to examine the effect of exogenous expression of the relevant mutant peptides on colocalization of $4.1 \mathrm{R}$ and NuMA in intact cells by confocal imaging (Figure 7). Expression of GFP (green) alone did not have any effect on the localization of NuMA. NuMA (red) was predominantly localized inside the nucleus in these cells. Exogenously expressed GFP-4.1R $10 \mathrm{kD}$ was localized mainly in the nucleus. In these cells, NuMA was also predominantly localized in the nucleus, but some irregularly arranged NuMA staining was also observed in the perinuclear region, and the nucleus was lobular. The yellow color generated by merger of the confocal images of GFP-4.1R $10 \mathrm{kD}$ and NuMA suggested that they partially colocalized inside the nucleus. GFP-4.1R $24 \mathrm{kD}$ was found to localize both in the cytoplasm and the nucleus, and partially colocalize with NuMA predominantly in the nucleus. GFP-4.1R $10+24 \mathrm{kD}$ was predominantly localized in the nucleus, but also diffusely localized inside the cytoplasm. However, it strongly colocalized with NuMA inside the nucleus. The colocalization of 4.1R domains with NuMA was in the order of $10 \mathrm{kD}<24 \mathrm{kD}<10+24 \mathrm{kD}$. However, GFP-4.1R $24 \mathrm{kD}$ with the tandem alanine mutations ( $4.1 \mathrm{R} 24 \mathrm{kD}$ mut $3 \mathrm{~A})$ failed to localize in the nucleus and colocalize with NuMA, and accumulated mainly inside the cytoplasm. The failure of GFP-4.1R $24 \mathrm{kD}$ mut3A to colocalize with NuMA in intact cells suggests that V762, V765, and V767 of 4.1R are necessary for association with NuMA, and are consistent with our results from yeast two-hybrid and in vitro binding assays.

Alanine substitutions of NuMA amino acids 1800-1805 abrogate nuclear localization of $4.1 \mathrm{R}$ and colocalization with $4.1 \mathrm{R}$

To validate the requirement of the NuMA amino acids identified to be necessary for interaction with $4.1 \mathrm{R}$ in intact mammalian cells, we compared the ability of transiently expressed GFPNuMA-C (aa 1785-2115) without or with alanine substitutions (NuMA-C mut6A) to colocalize with $4.1 \mathrm{R}$ in HeLa cells by confocal imaging. GFP-NuMA (green) was found to strongly localize in the nucleus (Figure 8). Some filamentous staining of GFP-NuMA was also observed in the cytoplasm consistent with an earlier observation that NuMA assembles into filamentous structures when expressed inside the cytoplasm. ${ }^{42}$ In these cells, 4.1R was mainly localized in the nucleus (red). The yellow color generated by merger of confocal images of GFP-NuMA and

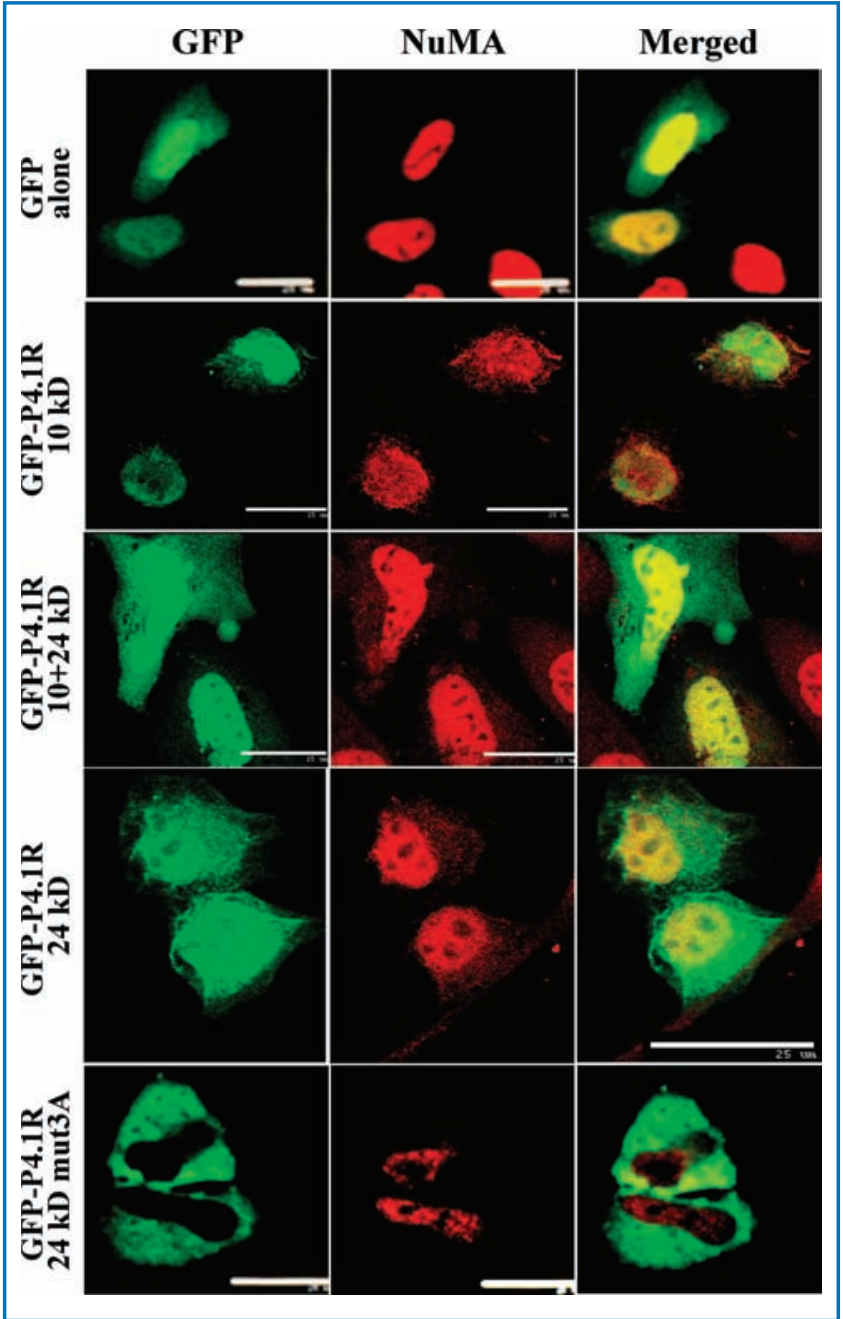

Figure 7. Mutagenization of V762, V765, and V767 of 4.1R to alanine inhibits transiently expressed GFP-4.1R 24 kD to colocalize with NuMA and localize in the nucleus. HeLa cells were transiently transfected with expression vectors encoding GFP alone or GFP-fusion proteins of 4.1R 10 kD, 10'24 kD, $24 \mathrm{kD}$ or the $24 \mathrm{kD}$ mutant (24 kD mut3A). After $24 \mathrm{~h}$ of transfection, cells were fixed, processed for immunofluorescent staining for NuMA (red), and analyzed by confocal microscopy. Yellow color generated by merger of confocal images of GFP (green) with NuMA indicates their colocalization.

4.1R suggest that they colocalized mostly inside the nucleus. In contrast, $4.1 \mathrm{R}$ was predominantly localized inside the cytoplasm and very weakly colocalized with the GFP-NuMA mutant (NuMA-C mut6A) inside the cytoplasm, although localization of the mutant NuMA was similar to that of the wild-type NuMA. The filamentous cytoplasmic localization of NuMA was not observed with expression of the mutant NuMA and the nuclear border was not apparent. No obvious colocalization was observed between the proteins inside the nucleus. Thus, our results suggest that residues 1800-1805 of NuMA are necessary for association with 4.1R. Since mutagenization of NuMA amino acids that inhibits its interaction with $4.1 \mathrm{R}$ prevented $4.1 \mathrm{R}$ to localize inside the nucleus, these results also suggest that 4.1R/NuMA interaction are likely to be required for nuclear localization of $4.1 \mathrm{R}$.

\section{Discussion}

The objective of this study was to ask whether interaction with NuMA is essential for the nuclear interaction of $4.1 \mathrm{R}$, and to identify the amino acids of $4.1 \mathrm{R}$ and NuMA that sustain their 


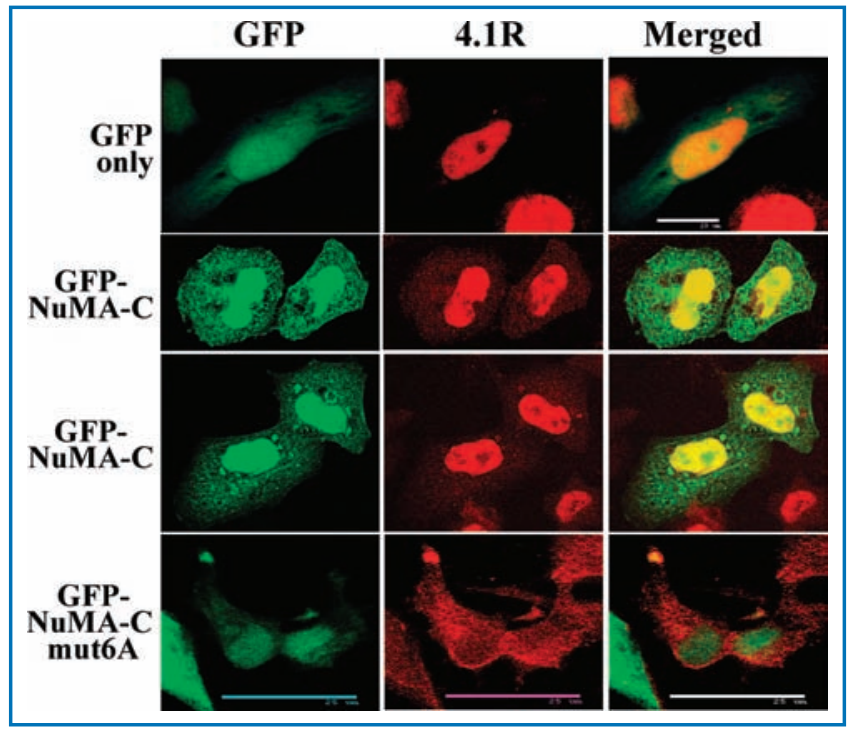

Figure 8. Mutagenization of NuMA aa 1800-1805 to alanine (NuMA-C mut6A) inhibits nuclear import of $4.1 R$ and colocalization with 4.1R. HeLa cells were transiently transfected with expression vectors encoding GFP alone, GFPNuMA-C (aa 1785-2115) or GFP-NuMA-C mut6A. After 24 h of transfection, cells were fixed, processed for immunofluorescent staining for 4.1R (red), and analyzed by confocal microscopy. Yellow color generated by merger of confocal images of GFP (green) with 4.1R indicates their colocalization.

interaction. Here, we report that amino acids V762, V765, and V767 of 4.1R, and I1800, I1801, I1803, T1804, and M1805 of NuMA are necessary for 4.1R/NuMA interaction. Alanine substitutions of V762, V765, and V767 of 4.1R $24 \mathrm{kD}$ peptide severely reduce its affinity for NuMA. Consistently, NuMA-C peptide with tandem alanine mutations of residues 1800-1805 does not bind to 4.1R. Exogenously expressed GFP-4.1R $10 \mathrm{kD}$ or $24 \mathrm{kD}$ domain peptides partially colocalize with NuMA in the nucleus, but GFP-4.1R $10+24 \mathrm{kD}$ peptides appear to better colocalize with NuMA. GFP-4.1R $24 \mathrm{kD}$ peptides with V672A, V765A, and V767A tandem mutations mainly accumulate in the cytoplasm, and do not colocalize with NuMA. Transiently expressed GFP-NuMA-C peptides (aa 1785-2115) predominantly colocalize with $4.1 \mathrm{R}$ inside the nucleus whereas the same NuMA peptides with tandem alanine substitutions of aa I1800-M1805 do not colocalize with $4.1 \mathrm{R}$, and also inhibit nuclear localization of $4.1 \mathrm{R}$.

4.1R has been reported to be crucial for normal organization and function of the nuclei, mitotic spindle and spindle poles. ${ }^{32,39-40}$ Inhibition of 4.1R and NuMA interaction by extraneous addition of 4.1R COOH-terminal domain peptides has been shown to disturb nuclear morphology in in vitro nuclear reconstitution assays using Xenopus egg extracts. ${ }^{32,39}$ Our results thus suggest that interaction of $4.1 \mathrm{R}$ and NuMA is necessary for localization of $4.1 \mathrm{R}$ inside the nucleus, and for the optimal organization and function of the mitotic apparatus.

Employing random- and site-directed-mutagenesis, we found I1800, I1801, I1803, T1804, and M1805 of NuMA, and V762, V765, and V767 of 4.1R to be necessary for their interaction. Since all of these amino acids have nonpolar side chains except T1804, our results imply that NuMA and 4.1R interaction is likely to be sustained by hydrophobic interactions. The reduced affinity of $4.1 \mathrm{R} 24 \mathrm{kD}$ mut3A for NuMA, and failure of NuMA-C mut6A to bind $4.1 \mathrm{R}$ observed in in vitro binding studies (Figure 6) were anticipated based on results obtained from yeast two-hybrid assays (Figure 3 and 5). These results are also consistent with the sixty-fold reduced affinity of NuMA for the mutant $4.1 \mathrm{R}$ observed by Krauss et al., ${ }^{39}$ who analyzed the in vitro interaction of wt- and mutant 4.1R peptides with NuMA based on identification of NuMA-binding residues of 4.1R initially reported by us. ${ }^{41}$ Additionally, transiently expressed GFP-fusion proteins of the mutant $4.1 \mathrm{R}$ or mutant NuMA poorly colocalized with their wild-type binding partners in intact HeLa cells. Collectively, these results suggest that V762, V765, and V767 of 4.1R, and I1800, I1801, I1803, T1804, and M1805 of NuMA are important and necessary for their interaction.

Although we found amino acids encoded by exons 20 and 21 of $4.1 \mathrm{R},{ }^{22}$ and specifically aa 727-735 in exon 20 (Figure 4) necessary for interaction with NuMA, none of the point mutations in exon 20 or alanine substitution of aa 727-735 was sufficient to inhibit interaction with NuMA (Figure 5). Thus, the importance of 4.1R exon 20 for interaction with NuMA needs further investigation. It is plausible that exon 20 may have an ancillary role in conjunction with exon 21 , such as providing a specific protein conformation that facilitates interaction with NuMA. Similar observations have been reported by Delhommeau, ${ }^{43}$ who analyzed the ability of two naturally occurring $4.1 \mathrm{R}$ exon 20 splicing mutants to colocalize with NuMA in intact cells, and to bind NuMA in vitro. The splicing mutant that lacks most of the exon 20-encoded peptide and carries a missense $\mathrm{COOH}$-terminal sequence (designated as Co.1) did not colocalize with NuMA. In contrast, the splicing mutant that lacks exon 20-encoded $\mathrm{COOH}$-terminal sequence but retains the exon 21-encoded COOH-terminal sequence (designated as Co.2) colocalized with NuMA. Both Co.1 and Co.2 failed to bind to NuMA in vitro. ${ }^{43}$ Thus, it is plausible that although both exon 20 and 21 of $4.1 \mathrm{R}$ are required for interaction with NuMA, exon 21 may have other binding partners that facilitate association with NuMA in intact cells.

In this study, we observed that GFP-4.1R $24 \mathrm{kD}$ and $10+24 \mathrm{kD}$ domains colocalize with NuMA inside the nucleus. GFP-4.1R $10 \mathrm{kD}$ also mainly localized inside the nucleus and partially colocalized with NuMA inside the nucleus, but overexpression of $4.1 \mathrm{R} 10 \mathrm{kD}$ domain caused a partial disruption in the nuclear organization as evidenced by non-uniform and lobular organization of the nucleus, and irregular perinuclear distribution of NuMA (Figure 8). In contrast, in a cell-free system of nuclear assembly involving Xenopus egg extracts, peptides that contained either 4.1R spectrin/actin- or NuMA-binding sites (exon 20-21), or the NuMA COOH-terminal peptide that comprised the 4.1R-binding sites, exerted inhibitory effects on organization of the nucleus, mitotic spindle and aster microtubules, and caused disorganization of preassembled mitotic structures. ${ }^{39,40}$

The effect of $4.1 \mathrm{R} 10 \mathrm{kD}$ and $24 \mathrm{kD}$ domain polypeptides could be different in intact cells compared to cell-free assays for multiple reasons. First, 4.1R and NuMA peptides may have better accessibility to their target molecules in cell-free assays than in intact cells. Second, in intact cells the nucleus is preorganized, and thus could be more resistant to the effects of exogenous $4.1 \mathrm{R}$ and NuMA peptides. Third, the dynamic regulation of nucleoskeletal structure provided by different factors, their coordinated organization, and spatial arrangement are dissolved in cell-free systems. Finally, HeLa cells used in our study could be less sensitive to $4.1 \mathrm{R}$ and NuMA peptides, since the effect on NuMA depletion ${ }^{44-47}$ and function of $4.1 \mathrm{R}^{48}$ have been reported to be celltype specific. $4.1 \mathrm{G}$, a ubiquitously expressed homologue of $4.1 \mathrm{R}^{10}$ that binds to $\mathrm{NuMA},{ }^{43}$ is also highly expressed in these cells, ${ }^{32}$ and could stabilize the nuclear structure by binding to NuMA. Thus, further investigation on the effect of $4.1 \mathrm{R}$ and NuMA peptides 
on the nuclear structure during nuclear reassembly such as cell division might reveal the precise effect of these peptides.

4.1R NuMA-binding and spectrin/actin-binding appears to be important for proper organization and function of the nucleus because GFP-4.1R $10+24 \mathrm{kD}$ domain was found to better colocalize with NuMA compared to either the $10 \mathrm{kD}$ or the $24 \mathrm{kD}$ domain alone, and overexpression of the $10 \mathrm{kD}$ spectrin actin binding domain caused a partial disruption in the nuclear organization. However, the role of $4.1 \mathrm{R}$ and nuclear spectrin/ actin-binding in nuclear architecture is not well understood. $4.1 \mathrm{R}$ may engage in functions analogous to its function in the erythrocyte cytoskeleton by binding to NuMA through its $24 \mathrm{kD}$ NuMA-binding domain and to nuclear actin/spectrin ${ }^{49}$ through its $\mathrm{SAB}$ domain. 4.1R could also stabilize or facilitate association between NuMA and the dynactin complex by binding to the actinrelated protein, Arp1. Arp1 associates with p150 glued, adducin and spectrin, ${ }^{50}$ and also binds to microtubules. ${ }^{51} 4.1 \mathrm{R}$ might bind to other intranuclear proteins involved in nuclear assembly.

The nuclear localization domains observed in our study do not match currently known molecular signals of $4.1 \mathrm{R}$ that regulate subcellular targeting of $4.1 \mathrm{R}$ isoforms. We found that exogenously expressed GFP-fusion proteins of $4.1 \mathrm{R} 10 \mathrm{kD}$, $24 \mathrm{kD}$ and $10+24 \mathrm{kD}$ domains localize in the nucleus (Figure 7). Although the $10 \mathrm{kD}$ and $10+24 \mathrm{kD}$ domains comprised the exon 16 that has been reported to facilitate nuclear import of $4.1 \mathrm{R}$, the $24 \mathrm{kD}$ domain did not contain the "core region" said to be necessary for nuclear localization ${ }^{24}$ or exon 16 . Since the same protein with the three alanine mutations did not localize to the nucleus, nuclear localization of GFP-4.1R $24 \mathrm{kD}$ domain peptide could not have been due to passive diffusion because of its small size. Additionally, nuclear localization of 4.1R was inhibited upon exogenous expression of GFP-NuMA-C mut6A polypeptides suggesting that conditions which inhibit 4.1R/NuMA interaction also inhibit nuclear localization of 4.1R. Therefore, we hypothesize that $4.1 \mathrm{R}$ and NuMA interaction may have a role in localization and function of $4.1 \mathrm{R}$ in the nucleus. Similar conclusions have also been made in an independent study based on the observation that the dominant negative effects of $4.1 \mathrm{R}$ $24 \mathrm{kD}$ and NuMA-C peptides on nuclear reassembly could be neutralized by their preincubation in a cell-free assay. ${ }^{39}$ Consistent with this hypothesis, mislocalization of NuMA has been observed in abnormal mitotic spindles of $4.1 \mathrm{R}$ knocked-down cells. ${ }^{52}$

\section{Acknowledgments}

We thank M. Delannoy of the Johns Hopkins University, Baltimore, MD for assistance with confocal microscopy. This work was supported by grant HL-44985 from the National Institute of Health to E.J. Benz, Jr.

\section{Conflict of Interest}

The authors have no conflict of interest.

\section{References}

1. Benz EJ, Jr. The erythrocyte membrane and cytoskeleton: Structure, function, and disorders. In: Stamatoyannopoulos G, Neinhuis AW, Majerus P, Varmus H, eds. The Molecular Basis of Blood Disease. 2nd Ed, Philadelphia, PA: Saunders; 1994: 257-292.

2. Granger $B L$, Lazarides E. Membrane skeletal protein 4.1 of avian erythrocytes is composed of multiple variants that exhibit tissue-specific expression. Cell. 1984; 37: 595-607.

3. Anderson RA, Correas I, Mazzucco C, Castle JD, Marchesi VT. Tissue-specific analogues of erythrocyte protein 4.1 retain functional domains. J Cell Biochem. 1988; 37: 269-284.

4. Parra MK, Gee SL, Koury MJ, Mohandas N, Conboy JG. Alternative $5^{\prime}$ exons and differential splicing regulate expression of protein 4.1R isoforms with distinct N-termini. Blood. 2003; 101: 4164-4171.
5. Huang SC, Baklouti F, Tang TK, Benz EJ, Jr. Differential utilization of translation initiation sites in alternatively spliced mRNAs arising from the Protein 4.1 gene. Trans Assoc Am Phys. 1992; 105: 165-171.

6. Chasis JA, Coulombel L, McGee S, Andrews K, Kan YW, Mohandas N. Differential use of protein 4.1 translation sites during erythropoiesis: implications for a mutation-induced stage-specific deficiency of protein 4.1 during erythroid development. Blood. 1996; 87: 5324-5331.

7. Tang TK, Quin Z, Marchesi VT, Benz EJ, Jr. Heterogeneity of mRNA and protein products arising from the protein 4.1 gene in erythroid and nonerythroid tissues. J Cell Biol. 1990; 110: 617624.

8. Conboy JG, Chan J, Chasis JA, Kan YW, Mohandas N. Tissue- and development-specific alternative RNA splicing regulates expression of multiple isoforms of erythroid membrane protein 4.1. J Biol Chem. 1991; 266: 8273-8280.

9. Subrahmanyam G, Bertics $P$, Anderson R. Phosphorylation of protein 4.1 on tyrosine-418 modulates its function in vitro. Proc Natl Acad Sci U S A. 1991; 88: 5222-5226.

10. Parra MP, Gascard LD, Walensky SH, Snyder SH, Mohandas N, Conboy JG. Cloning and characterization of 4.1G (EPB41L2), a new member of the skeletal protein 4.1 (EPB41) gene family. Genomics. 1998; 49: 298-306.

11. Parra M, Gacard $P$, Walensky, LD, Tkakuwa JA, Berger $T$, Lee $G$, Chasis JA, Snyder SH, Mohandas $\mathrm{N}$, Conboy JG. Molecular and functional characterization of protein $4.1 \mathrm{~B}$, a novel member of the protein 4.1 family with high level focal expression in the brain. J Biol Chem. 2000; 275: 3247-3255.

12. Walensky LD, Blackshaw $S$, Liao $D$, Watkins $C C$, Weier HU, Parra M, Huganir RL, Conboy JG, Mohandas N, Snyder SH. A novel neuron-enriched homolog of the erythrocyte membrane cytoskeletal protein 4.1. J Neurosci. 1999; 19: 6457-6467.

13. Cohen CM, Foley SF, Korsgen C. A protein immunologically related to erythrocyte band 4.1 is found on stress fibers of non-erythroid cells. Nature (Lond.). 1982; 299: 648-650.

14. Lue RA, Marfatia SM, Branton D, Chishti AH. Cloning and characterization of hdlg: The human homologue of the Drosophila discs large tumor suppresser binds to protein 4.1. Proc Natl Acad Sci U S A. 1994; 91: 9818-9822.

15. Mattagajasingh SN, Huang SC, Hartenstein JS, Snyder M, Marchesi VT, Benz EJ, Jr. A nonerythroid isoform of protein 4.1R interacts with the nuclear-mitotic apparatus (NuMA) protein. $J$ Cell Biol. 1999; 145: 29-45.

16. Leto $\mathrm{TL}$, Pratt BM, Madri JA. Mechanisms of cytoskeleton regulation: modulation of aortic endothelial cell protein band 4.1 by the extracellular matrix. J Cell Physiol. 1986; 127: 423-431. 17. Chasis JA, Coulombel L, Conboy J, McGee S, Andrews K, Kan YW, Mohandas N. Differentiationassociated switches in protein 4.1 expression: Synthesis of multiple structural isoforms during normal human erythropoieses. J Clin Invest. 1993; 91: 329-338.

18. Madri JA, Pratt BM, Yannariello-Brown J. Endothelial cell-extracellular matrix interactions. In: Simionescu N, Simionescu M, eds. Endothelial Cell Biology in Health and Disease. New York: Plenum Press; 1988: 167-188.

19. Correas I. Characterization of isoforms of protein 4.1 present in the nucleus. Biochem J. 1991; 279: 581-585.

20. De Carcer G, Lallena MJ, Correas I. Protein 4.1 is a component of the nuclear matrix of mammalian cells. Biochem J. 1995; 312: 871-877.

21. Krauss SW, Larabell CA, Lockett $S$, Gascard P, Penman S, Narla M, Chasis JA. Structural protein 4.1 in the nucleus of human cells: Dynamic rearrangements during cell division. J Cell Biol. 1997a; 137: 275-289.

22. Mattagajasingh SN, Huang SC, Hartenstein JS, Benz EJ, Jr. Characterization of the interaction between protein 4.1R and ZO-2. A possible link between the tight junction and the actin cytoskeleton. J Biol Chem. 2000; 275: 30573-30585.

23. Luque $\mathrm{CM}$, Lallena MJ, Alonso MA, Correas I. An alternative domain determines nuclear localization in multifunctional protein 4.1. J Biol Chem. 1998; 273: 11643-11649.

24. Luque $C M$, Correas I. A constitutive region is responsible for nuclear targeting of $4.1 \mathrm{R}$ : modulation by alternative sequences results in differential intracellular localization. J Cell Sci. 2000; 113: 2485-2495.

25. Hung L, Tang CC, Tang TK. Protein $4.1 R-135$ interacts with a novel centrosomal protein (CPAP) which is associated with the $\gamma$-tubulin complex. Mol Cell Biol. 2000; 20: 7813-7825.

26. Leclerc $E$, Vetter $S$. Characterization of a calcium-dependent calmodulin-binding domain in the 135-kD human protein 4.1 isoform. Eur J Biochem. 1998; 258: 567-571.

27. Marfatia SM, Lue R, Branton $D$, Chishti AH. Identification of the protein 4.1 binding interface on glycophorin $\mathrm{C}$ and p55, a homologue of the Drosophila discs-large tumor suppresser protein. J Biol Chem. 1995; 270: 715-719.

28. Tanaka T, Kadowaki K, Lazarides $E$, Sobue K. Ca ${ }^{2+}$-dependent regulation of the spectrin/actin interaction by calmodulin and protein 4.1. J Biol Chem. 1991; 266: 1134-1140.

29. Jöns T, Drenckhahn D. Identification of the binding interface involved in linkage of cytoskeletal protein 4.1 to the erythrocyte anion exchanger. EMBO J. 1992; 11: 2863-2867.

30. Nunomura W, Takakuwa $Y$, Tokimitsu R, Krauss SW, Kawashima M, Mohandas N. Regulation of CD44-protein 4.1 interaction between $\mathrm{Ca}^{2+}$ and calmodulin. Implications for modulation of CD44-ankyrin interaction. J Biol Chem. 1997; 272: 30322-30328.

31. Tang CC, Tang TK. The 30-kD domain of protein 4.1 mediates its binding to the carboxyl terminal of plCln, a protein involved in cellular volume regulation. Blood. 1998; 92: 1442-1447.

32. Huang SC, Jagadeeswaran R, Liu ES, Benz EJ, Jr. Protein $4.1 R$, a microtubule-associated protein involved in microtubule aster assembly in mammalian mitotic extract. J Biol Chem. 2004; 279: 34595-34602. 
33. Horne WC, Huang SC, Baker PS, Tang TK, Benz EJ, Jr. Tissue-specific alternative splicing of protein 4.1 inserts an exon necessary for formation of the ternary complex with erythrocyte spectrin and F-actin. Blood. 1993; 82: 2558-2563.

34. Discher DE, Parra M, Conboy JG, Mohandas N. Mechanochemistry of the alternatively spliced spectrin-actin binding domain in membrane skeletal protein 4.1. J Biol Chem. 1993; 268: 71867195.

35. Correas I, Avila J. Erythrocyte protein 4.1 associates with tubulin. Biochem J. 1988; 255: 217-221

36. Gascard P, Lee G, Coulombel L, Auffray I, Parra M, Conboy JG, Mohandas N, Chasis JA. Characterization of multiple isoforms of protein 4.1 during erythroid terminal differention. Blood. 1998; 92: 4404-4414.

37. Walensky LD, Gascard P, Fields ME, Blackshaw S, Conboy JG, Mohandas N, Snyder HS. The 13-kD FK506 binding protein, FKBP13, interacts with a novel homologue of the erythrocyte membrane cytoskeletal protein 4.1. J Cell Biol. 1998; 141: 143-153.

38. Hou C, Tang CC, Roffler SR, Tang TK. Protein $4.1 R$ binding to elF3-p44 suggests an interaction between the cytoskeletal network and the translation apparatus. Blood. 2000; 96: 747-753.

39. Krauss SW, Heald R, Lee G, Nunomura W, Gimm JA, Mohandas N, Chasis JA. Two distinct domains of protein 4.1 critical for assembly of functional nuclei in vitro. J Biol Chem. 2002; 277: 44339-44346.

40. Krauss SW, Lee $G$, Chasis JA, Mohandas $N$, Heald R. Two protein 4.1 domains essentia for mitotic spindle and aster microtubule dynamics and organization in vitro. J Biol Chem. 2004; 279: 27591-27598.

41. Mattagajasingh SN, Huang SC, Benz EJ, Jr. Amino acid residues in Nuclear Mitotic Apparatus Protein (NuMA) critical for its interaction with protein 4.1 [abstract]. Blood. 1997; 90:408a.

42. Saredi $A$, Haward $L$, Campton DA. NuMA assembles into an extensive filamentous structure when expressed in the cell cytoplasm. J Cell Sci. 1996; 109: 619-630.
43. Delhommeau F, Vasseur-Godbillon C, Leclerc $P$, Schischmanoff $P$, Croisille L, Rince P, Moriniere $M$ Benz EJ, Jr, Tchernia G, Tamagnini G, Ribeiro L, Delaunay J, Baklouti F. A splicing alteration of 4.1R pre-mRNA generates 2 protein isoforms with distinct assembly to spindle poles in mitotic cells. Blood. 2002; 100: 2629-2636.

44. Price $C M$, Pettijohn DE. Distribution of the nuclear mitotic apparatus protein (NuMA) during mitosis and nuclear assembly. Exp Cell Res. 1986; 166: 295-311.

45. Compton DA, Cleveland DW, NuMA is required for the proper completion of mitosis. J Cell Biol. 1993; 120: 947-957.

46. Merdes A, Ramyar K, Vechio LD, Cleveland DW. A complex of NuMA and cytoplasmic dynein is essential for mitotic spindle assembly. Cell. 1996; 87: 447-458.

47. Taimen $P$, Viljamaa M, Kallajoki M. Preferential expression of NuMA in the nuclei of proliferating cells. Exp Cell Res. 2002; 256: 140-149.

48. Olave IA, Reck-Peterson $\mathrm{SL}$, Crabtree GR. Nuclear actin and actin-related proteins in chromatin remodeling. Ann Rev Biochem. 2002; 71: 755-781.

49. Pérez-Ferreiro $C M$, Luque $C M$, Correas I. 4.1R proteins associate with interphase microtubules in human T cells. A 4.1R constitutive region is involved in tubulin binding. J Biol Chem. 2001; 276: 44785-44791.

50. Holleran EA, Tokito MK, Karki S, Holzbour ELF. Centractin (ARP1) associates with spectrin revealing a mechanism to link dynactin to intracellular organelles. J Cell Biol. 1996; 135: 18151829.

51. Waterman-Storer, C. M., Kirki, S., Holzbaur E. The $p 150^{\text {glued }}$ component of the dynactin complex binds to both microtubule and the actin related protein centractin (Arp-1). Proc Natl Acad Sci U S A. 1995; 92: 1634-1638.

52. Krauss SW, Spence JR, Bahmanyar $S$, Barth AIM, Go MM, Czerwinski D, Meyer AJ. Downregulaton of protein $4.1 \mathrm{R}$, a mature centriole protein, disrupts centrosomes, alters cell cycle progression, and perturbs mitotic spindle and anaphase. Mol Cell Biol. 2008; 28: 2283-2294. 